\title{
Pengaruh Tegangan dan Beban Daya Listrik terhadap Arus dan Putaran Mesin pada Gentset Berbahan Bakar LPG
}

\author{
Subur Mulyanto ${ }^{1}$, Mikail Eko Prasetyo Widagda ${ }^{2}$ \\ ${ }^{1}$ Jurusan Teknik Mesin-Politeknik Negeri Balikapapan \\ ${ }^{2}$ Jurusan Teknik Elektro-Politeknik Negeri Balikpapan \\ subur.mulyanto@poltekba.ac.id
}

\begin{abstract}
ABSTRAK
Penelitian ini bertujuan untuk mengetahui pengaruh tegangan dengan beban daya listrik yang dibebankan pada genset LPG terhadap besar arus dan putaran mesin pada genset tersebut. Generator listrik yang berbahan bakar LPG akan diberikan pembebanan lampu kemudian mengamati putaran engine dan arus listrik yang dihasilkan dengan tegangan yang distabilkan yaitu 220 Volt. Dalam pengamatan ini dilakukan beberapa variasi, diantaranya 3 (tiga) variasi putaran mesin awal, yaitu, 2000, 2500, dan 3000 Rpm. Sedangkan pembebanan ada 7 (tujuh) variasi, yaitu, 120, 180, 240, 360, 480, 540, dan 720 Watt. Dari hasil penelitian yang dilakukan dapat dilihat bahwa pada putaran mesin awal 2000 Rpm putaran mulai tidak stabil pada beban 240 Watt, yaitu sebesar $1321 \mathrm{Rpm}$ dengan arus sebesar 1,5 Ampere. Kemudian dilanjutkan pengamatan pada putaran awal mesin $2500 \mathrm{Rpm}$ putaran mulai tidak stabil pada beban $720 \mathrm{~W}$, yaitu sebesar 1232 Rpm dengan arus sebesar 2,9 Ampere. Pada variasi ketiga yaitu putaran mesin awal 3000 Rpm putaran masih stabil sampai beban 720 Watt, yaitu sebesar $1521 \mathrm{Rpm}$ dengan arus 2.9 Ampere. Dari pengamatan di atas disimpulkan bahwa untuk penggunaan genset listrik LPG ini menggunakan putaran awal 2500 Watt dengan daya maksimal 540 Watt untuk mencapai putaran dan arus yang stabil, yaitu > 1500 Rpm dan >2 Ampere.
\end{abstract}

Kata Kunci: Genset LPG, putaran mesin, arus, tegangan, daya beban

\section{ABSTRACT}

The Effect of Voltage and Load Power to Current and Engine Rotation on LPG Generators. This study aims to determine the effect of voltage and an electric power charge charged to the LPG generator on the large current and engine speed at the generator. LPG generators will be given a lamp then observe the engine rotation and electric current generated with a stabilized voltage of 220 Volts. In this observation several variations were made, including three variations of the initial engine speed, namely, 2000, 2500, and 3000 Rpm. While loading there are seven variations, namely, 120, 180, 240, 360, 480, 540, and 720 Watt. The research results, carried out it can be seen that at the initial engine speed of 2000 Rpm the rotation starts to become unstable at a load of 240 Watt, which is 1321 Rpm with a current of 1.5 Ampere. Then the observation is continued at the initial engine rotation of 2500 Rpm. The rotation starts unstable at a load of 720 Watt, which is 1232 Rpm with a current of 2.9 Amperes. In the initial engine rotation d of 3000 Rpm is still stable until the load is 720 Watt, which is 1521 Rpm with a current of 2.9 Amperes. From the above observations it is concluded that for the use of this LPG generator uses an initial rotation of 2500 Watt with a maximum power of 540 Watt to achieve a stable rotation and current, which is $>1500$ Rpm and> 2 Amperes

Keywords : LPG Generators, engine rotation, current, voltage, load power

\section{PENDAHULUAN}

Keberadaan energi listrik juga sangat berpengaruh demi berjalannya kehidupan sehari-hari hingga pembangunan ekonomi dan sosial. Kondisi seperti ini akan mengurangi persediaan bahan bakar minyak sebagai bahan bakar utama untuk membangkitkan energi listrik, sementara harga bahan bakar minyak dunia meningkat secara signifikan [1], [10]. Untuk memenuhi kebutuhan energi listrik yang terus meningkat, dibutuhkan sumber energi lain yang dapat menggantikan dan mengurangi peranan bahan bakar minyak. Salah satu pengganti bahan bakar pengganti minyak adalah bahan bakar gas LPG [2],[3] ke Gas ini perlu didukung oleh semua pihak yang terlibat. Sebagai salah satu bentuk respon untuk mendukung program konversi ini, maka dalam kesempatan ini ditampilkan mesin-mesin bermotor 
yang dapat dikonversi dari Bahan Bakar Minyak (BBM) ke Gas. Namun dengan beralihnya bahan bakar minyak ke bahan bakar gas, bukan tidak ada permasalahan yang timbul. misalnya seperti efisiensi penggunaan bahan bakar, kestabilan arus atau tegangan yang dihasilkan. hal tersebut dikarenakan banyak faktor yang mempengaruhinya baik dari segi teknis equipmentnya maupun kondisi environmentnya[2].

Atas hal tersebut di atas, peneliti ingin melakukan pengamatan yang memfokuskan pada salah satu faktor yaitu kestabilan tegangan. Pengamatan yang dilakukan adalah dengan melihat putaran mesin pada engine berbahan bakar LPG tersebut yang mampu menghasilkan tegangan stabil pada saat pembebanan. Dari pengamatan yang dilakukan di atas diharapkan mampu mendapatkan informasi terkait kestabilan tegangan yang dihasilkan oleh genset berbahan bakar LPG jika dibebani listrik.

Generator listrik merupakan perangkat mesin yang bertjuan untuk mengubah tenaga mekanis menjadi tenaga listrik melalui proses induksi elektromagnetik yang nantinya disebut sebagai pembangkit [5]. Energi yang didapatkan oleh generator ini adalah dari energi mekanis dari prime mover. Generator arus bolak-balik (AC) dikenal dengan sebutan alternator. Generator pembangkit untuk mensuplai kebutuhan energi listrik. Adapun genset (generator set) sendiri bagian dari generator. Genset ialah suatu alat yang dapat mengubah energi mekanik menjadi energi listrik [13]. Genset atau sistem generator penyaluran adalah suatu generator listrik yang terdiri dari panel, berenergi solar dan terdapat kincir angin yang ditempatkan pada suatu tempat.

Genset mampu digunakan sebagai system cadangan listrik atau "off-grid" (sumber daya yang tergantung atas kebutuhan pemakai). Genset dipakai oleh rumah sakit dan industri yang menginginkan sumber listrik yang besar dan relatif stabil. Namun juga dapat dipakai pada skala rumahan. Generator terpasang satu poros dengan motor diesel, yang biasanya memakai generator sinkron (alternator) pada pembangkitan [13]. Generator sinkron mempunyai dua bagian utama yaitu: sistem medan magnet dan jangkar. Generator ini kapasitasnya besar, medan magnetnya berputar karena terletak pada rotor.

Sebuah benda bermuatan positif kalau benda tersebut kehilangan elektron dan bermuatan negatif kalau benda tersebut kelebihan elektron. Dalam keadaan berbeda muatan inilah munculnya tenaga potensial yang berada di antara benda-benda itu. Karena itu bila sepotong kawat penghantar dihubungkan diantara kedua benda yang berbeda muatan menyebabkan terjadinya perpindahan energi diantara benda-benda itu [11]. Peralihan energi ini berlangsung terus selama ada beda tegangan. Terjadinya tegangan disebabkan adanya beda tiap muatan mempunyai tenaga potensial untuk menggerakkan suatu muatan lain dengan cara menarik atau menolak.

Beda tegangan dapat dihasilkan dengan memberikan tekanan listrik dari suatu pembangkit listrik pada salah satu tempat penghantar. Satuan untuk mengukur tegangan listrik adalah volt [4],[5]. Beda tegangan dapat berubah-ubah, dari seperjuta volt sampai beberapa juta volt. Beda tegangan diantara terminal - terminal dari PLN ada yang 110 volt atau 220 volt, beda tegangan diantara dua terminal aki adalah 6 volt atau 12 volt, sedangkan beda tegangan pada baterai umumnya 1,5 volt [9], [12], [15]

\section{Kestabilan Tegangan Listrik}

Salah satu faktor pada kestabilan sistem tenaga adalah stabilitas tegangan. Stabilitas tegangan ialah kemampuan dari sistem untuk menjaga nilai teganggan pada batas yang ditentukan baik sebelum, selama dan setelah terjadi gangguan [8]. Sistem mengalami kondisi tidak stabil ketika terjadi gangguan, perubahan beban. Stabilitas tegangan terbagi menjadi dua, yaitu stabilitas tegangan akibat gangguan yang kecil dan akibat gangguan yang luas. Stabilitas tegangan akibat gangguan kecil ini terjadi akibat gangguan yang kecil atau bersifat lokal, seperti perubahan kenaikan beban di sistem[5].

Sedangkan pada stabilitas akibat gangguan besar adalah kemampuan sistem untuk mempertahankan tegangan pada batas operasi yang ditentukan akibat terjadi gangguan yang besifat luas, seperti kesalahan sistem, pelepasan generator, atau kontingensi pada jaringan. Keadaan tersebut membuat sistem harus mendapatkan kembali kestabilannya [5], [8].

Berdasarkan waktu kestabilan tegangan sistem akan kembali dalam waktu cepat atau lama tergantung dari jenis gangguannya. Klasifikasi stabilitas tegangan berdasarkan periode kestabilan dapat dibagi menjadi tiga macam, yaitu stabilitas tegangan jangka pendek, jangka menengah dan jangka panjang [6]. Rentang waktu stabilitas tegangan 
jangka pendek adalah 0 sampai 10 detik, jangka menengah adalah antara 10 detik sampai 10 menit, sedangkan jangka panjang lebih dari 10 menit [5], [6].

Adapun pengaruh ketidakstabilan tegangan dapat menyebabkan beberapa hal pada peralatan listrik antara lain:

1. Mengurangi intensitas cahaya keluaran dari lampu listrik yang seterusnya dapat mengakibatkan umur lampu yang lebih pendek.

2. Mengurangi efesiensi pada peralatan-peralatan pemanas yang menggunakan listrik.

3. Menaikan rugi-rugi daya, memperpendek umur rotor akibat perubahan daya dan torsi pada generator dan motor sinkron.

4. Merubah torsi dan slip pada motor induksi yang dapat mengakibatkan getaran yang berlebihan, mengurangi kekuatan mekanis dan memperpendek umur pelayanan motor induksi.

5. Mengurangi waktu pelayanan dan efesiensi operasiaonal dari peralatan elektroliser sehingga menaikan operasi dan perawatan.

6. Menyebabkan kegagalan komutasi dan merusak komponen sistem pada peralatan listrik yang menggunakan penyearah.

\section{METODE PENELTIAN}

Penelitian ini dilakukan di workshop teknik mesin dan laboratorium kimia Politeknik Negeri Balikpapan. Peralatan yang digunakan antara lain, Genset dengan bahan bakar LPG, Panel alat uji yang di rangkai dengan simulasi beban lampu dilengkapi dengan voltmeter dan Amperemeter, Tachometer dan Multimeter

\section{Desain Perancangan Alat Uji}

Alat uji dibuat untuk simulasi pembebanan. yakni menggunakan lampu pijar sebagai media bebannya. Rangkaian lampu disusun pada panel yang dilengkapi dengan Amperemeter dan Voltmeter seperti pada gambar 1 .

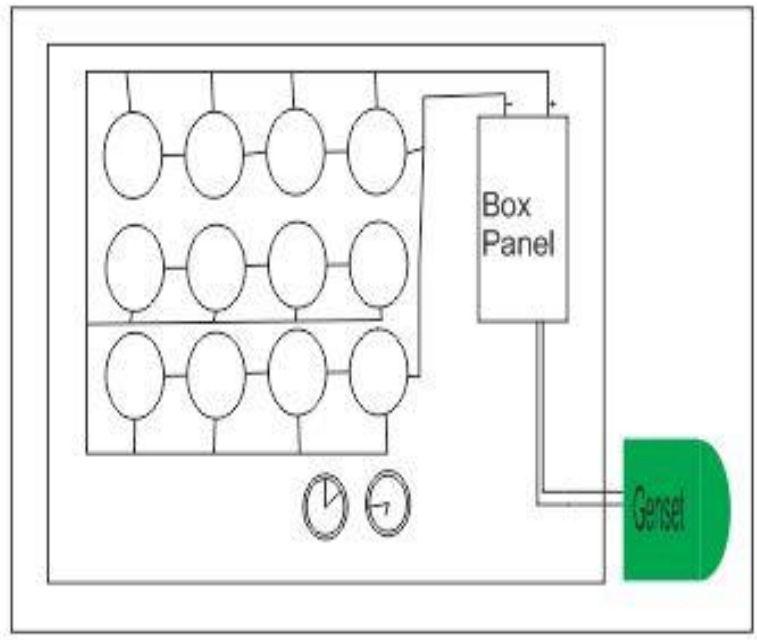

Dalam rangkaian seperti pada gambar 1, jumlah fiting lampu adalah sebanyak 12 (dua belas) buah. Lampu yang digunakan ada 2 daya, yaitu lampu daya 40 Watt dan lampu 60 Watt, jadi untuk melakukan simulasi beban daya yang diinginkan bisa menyesuiakan dengan beban daya lampu masing-masing.

Proses dan hasil perancangan alat uji seperti pada gambar 2 dan gambar 3.

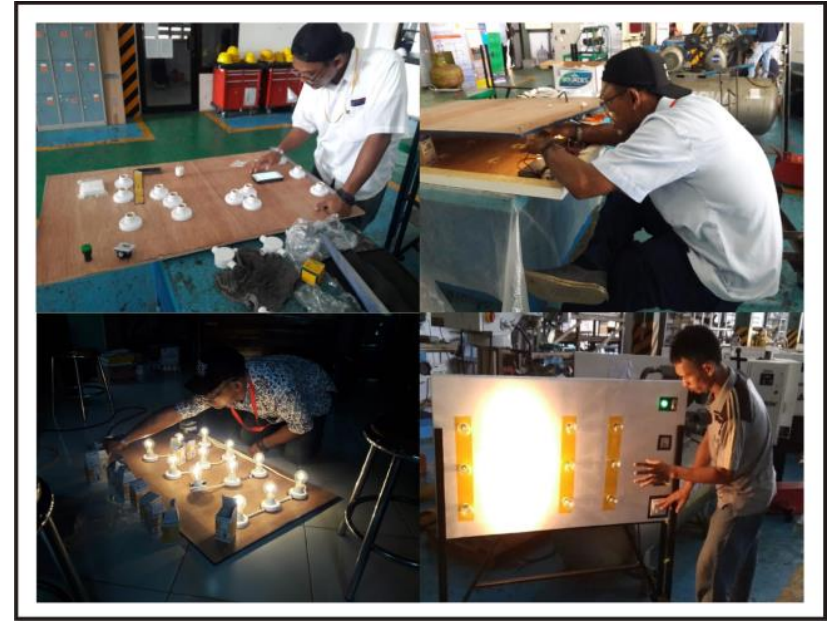

Gambar 2. Proses perancangan dan pembuatan panel alat uji. 


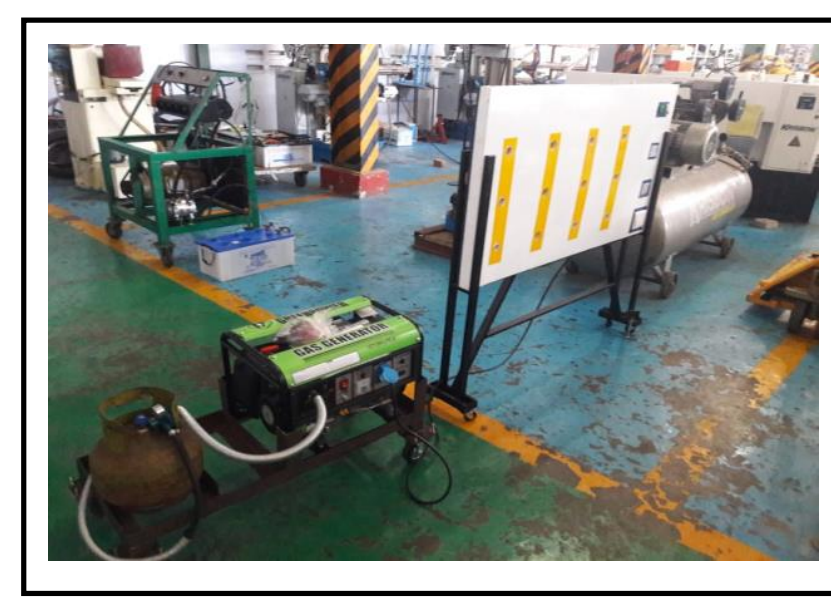

Gambar 3. Panel alat uji.

\section{Alur Penelitian}

Langkah-langkah penelitian yang dilakukan sesuai dengan alur penelitian sesuai pada gambar 4 .

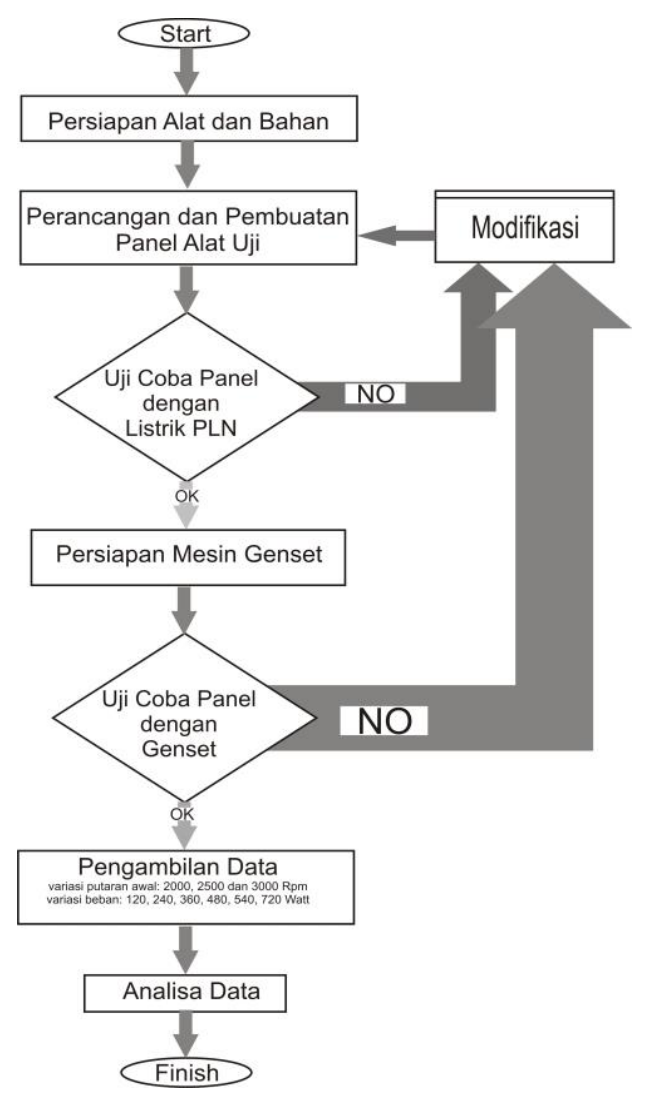

Gambar 4. Diagram Alur Penelitian

\section{Proses Pengujian}

Sebelum proses pengujian dilakukan warming up kurang lebih 20 menit untuk mencapai temperatur kerja. Setelah mesin sudah selesai warming up, panel yang sudah dipasang lampu siap untuk di hubungkan dengan arus keluaran dari genset dengan variasi beban antara lain 120, 249, 360, 480, 540, dan 720 Watt pada variasi putaran awal mesin 2000, 2500, dan $3000 \mathrm{Rpm}$. Dari masing-masing variasi diamati dan dicatat datanya kemudian dibuatkan table berikut grafik, khususnya pada putaran mesin ketika ditambah beban dan besar arus yang keluar.

\section{HASIL DAN PEMBAHASAN}

Dari hasil pengujian didapatkan data seperti pada tabel 1 .

Tabel 1. Hasil pengujian genset listrik dengan simulasi pembebanan lampu

\begin{tabular}{|c|c|c|c|c|}
\hline & $\begin{array}{c}\text { Tegangan } \\
\text { (V) }\end{array}$ & $\begin{array}{c}\text { Daya } \\
(\mathrm{W})\end{array}$ & $\begin{array}{l}\text { Arus } \\
\text { (A) }\end{array}$ & $\begin{array}{c}\text { Putaran } \\
\text { (Rpm) }\end{array}$ \\
\hline \multirow{8}{*}{ 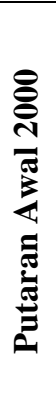 } & 220 & 0 & 0 & 2000 \\
\hline & 220 & 120 & 0.4 & 1965 \\
\hline & 220 & 180 & 0.9 & 1954 \\
\hline & 220 & 240 & 1.5 & 1321 \\
\hline & 220 & 360 & 1.8 & 1212 \\
\hline & 220 & 480 & 2 & 1000 \\
\hline & 220 & 540 & 2.4 & 950 \\
\hline & 220 & 720 & 2.9 & 870 \\
\hline \multirow{7}{*}{ 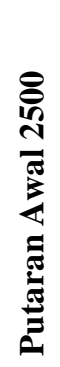 } & 220 & 0 & 0 & 2500 \\
\hline & 220 & 120 & 0.4 & 2458 \\
\hline & 220 & 180 & 0.9 & 2423 \\
\hline & 220 & 240 & 1.5 & 2298 \\
\hline & 220 & 360 & 1.8 & 2004 \\
\hline & 220 & 480 & 2 & 1871 \\
\hline & 220 & 540 & 2.4 & 1667 \\
\hline \multirow{9}{*}{ 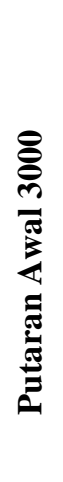 } & 220 & 720 & 2.9 & 1232 \\
\hline & 220 & 0 & 0 & 3000 \\
\hline & 220 & 120 & 0.4 & 3000 \\
\hline & 220 & 180 & 0.9 & 2870 \\
\hline & 220 & 240 & 1.5 & 2743 \\
\hline & 220 & 360 & 1.8 & 2345 \\
\hline & 220 & 480 & 2 & 1976 \\
\hline & 220 & 540 & 2.4 & 1864 \\
\hline & 220 & 720 & 2.9 & 1521 \\
\hline
\end{tabular}


Berdasarkan hasil pengujian yang disajikan pada tabel 1 di atas terlihat bahwa putaran mesin genset turun secara signifikan pada putaran mesin awal 2000 Rpm dengan beban 240 Watt. Putaran mesin turun hingga $>1500 \mathrm{Rpm}$. Sedangkan pada putaran mesin awal $2500 \mathrm{Rpm}$ putaran masih > $1500 \mathrm{Rpm}$ yaitu sebesar $1664 \mathrm{Rpm}$ pada 540 Watt dengan arus 2,4 Ampere. Dan variasi putaran mesin awal 3000Rpm, putaran masih stabil hingga beban 720 Watt. Hasil pengujian juga disajikan dalam grafik seperti pada gambar 5 .

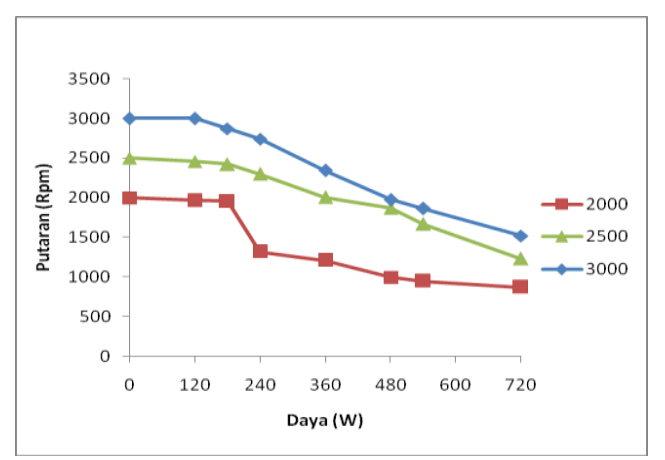

Gambar 5. Pengaruh beban terhadap putaran mesin

Sedangkan grafik dibawah menunjukkan hubungan pengaruh antara daya terhadap kuat arus yang dialirkan dari genset ke beban pada panel. Grafik dapat dilihat pada gambar 6 .

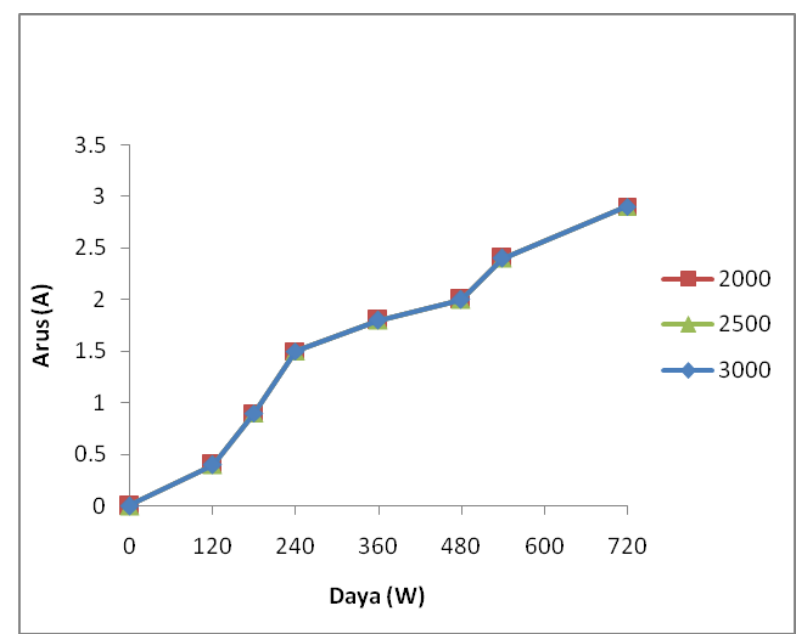

Gambar 6. Hubungan beban terhadap arus

Gambar 6 menunjukkan grafik hubungan beban terhadap arus. Dapat dilihat bahwa dari masingmasing variasi putaran awal dengan masing-masing pembebanannya tidak menunjukkan perbedaan arus yang dialirkan. Sehingga dalam hal ini arus listrik tidak dipengaruhi oleh kecepatan putaran mesin awal, tetapi dipengaruhi oleh daya yang dibebankan terhadap genset. Sedangkan pada gambar 5 yang menunjukkan adanya pengaruh daya yang dibebankan terhadap kecepatan putaran mesin awal, pada grafik tersebut terlihat bahwa ada perbedaan putaran mesin saat penambahan beban. Data pada tabel 1 dan grafik pada gambar 5 memperlihatkan bahwa pada putaran mesin awal 3000Rpm menunjukkan bahwa putaran masih tetap stabil hingga beban daya sebesar 720 Watt, namun untuk keamanan putaran mesin awal 3000 mengalami kendala yaitu mesin hunting. Hal ini dikarenakan untuk mencapai putaran mesin awal 3000Rpm. Throttle gas harus dibuka penuh, sehingga berakibat komposisi bahan bakar (LPG) tidak mampu mengimbangi udara yang masuk ke dalam ruang bakar. Sehingga variasi yang terbaik pada genset LPG adalah pada putaran mesin awal 2500Rpm dengan Beban maksimal 540 Watt.

\section{KESIMPULAN}

Adapun kesimpulan yang dapat diambil dari hasil penelitian ini adalah kecepatan putaran mesin awal $2000 \mathrm{Rpm}$ putaran mulai tidak stabil pada beban 240 Watt, yaitu sebesar $1321 \mathrm{Rpm}$ dengan arus sebesar 1,5 Ampere, Kecepatan putaran awal mesin 2500 Rpm putaran mulai tidak stabil pada beban 720 Watt, yaitu sebesar $1232 \mathrm{Rpm}$ dengan arus sebesar 2,9 Ampere, pdda variasi ketiga yaitu putaran mesin awal $3000 \mathrm{Rpm}$ putaran masih tetap stabil hingga beban 720 Watt yaitu sebesar 1521 Rpm. Variasi terbaik untuk genset LPG yang dijadikan obyek penelitian adalah kecepatan putaran mesin awal 2500 Rpm dengan beban daya maksimal 540 Watt

\section{DAFTAR PUSTAKA}

[1] Y. S. Indartono, "Krisis Energi di Indonesia: Mengapa dan Harus Bagaimana," Majalh Inovasi, vol. 18, 2008.

[2] Ika Kuniarty, Heri Hermansyah, "Potensi Pemanfaatan LPG sebagai Bahan Bakar Bagi Pengguna Kendaraan Bermotor," Prosiding Semnastek, 2016.

[3] Indarto, "Pemakaian Bahan Bakar Gas MEnjadi Alternatif bagi Kendaraan Bermotor Berbahan 
Bakar Premium," Gema Teknologi, pp. 18-21, 2012.

[4] A. Faisa, "Analisa Pengaruh Perbandingan Pembebanan Resitif, Induktif, Kapasitif dan Kombinasi Beban RLC terhadap Regulasi Tegangan dan Efisiensi pada Generator Sinkron 3 Fasa," Jurnal Teknik Elektro USU Medan, 2011.

[5] S. Wahyudi, Proteksi Sistem Distribusi Tenaga Lsitrik, Depok: Garamond, 2012.

[6] Hari Prasetijo, Ropiudin, Budi Dharmawan, "Generator Magnet Permanen sebagai Pembangkit Listrik Putaran Rendah.," Dinamika Rekayasa, vol. 8, 2012.

[7] Tutun Nugraha, P.hD, Didik Sunardi, Dipl-Ing, Seri Sains Energi Tebarukan Energi Angin, Jakarta: PT, Pelangi Nusantara, 2012.

[8] A. Beiser, Konsep Fisika Modern, Jakarta: Erlangga, 1992.

[9] A. Kadir, Energi, Sumber Daya, Inovasi, Tenaga Listrik dan Potensi Ekonomi, Jakarta: UI-Press, p. 1995.

[10] Nuareni Priyaningsih, Nurhening Yuniarti, "Analisis Efisiensi Generator pada Wind Turbine," Jurnal Edukasi Elektro, vol. 1, 2017.

[11] Zuhal, Dasar Teknik Tenaga Listrik dan Elektronika Daya, Jakarta: PT. Gramedia Pustaka Utama, 1995.

[12] S. Trihadi, "Rancangan Teknis dan Implementasi Sistem Pembangkit Listrik Hibrida PV-Diesel di Sulawesi," Jurnal Ilmiah Teknologi Energi, vol. 1, 2006.

[13] M. Sumanto, Motor Listrik Arus Bolak Balik, Yogyakarta: Andi, 1993.

[14] C. L. Eugene, Mesin dan Rangkaian Listrik,
Jakarta: Erlangga, 1993.

[15] W. D. Stevenson, Analisis Sistem Tenaga Listrik Edisi ke empat, Jakarta: Erlangga, 1994. 